\title{
THE ANALYSIS OF THE EMERGENCE AND DEVELOPMENT OF FEMALE ENTREPRENEURSHIP IN ROMANIA
}

\author{
Dorina Ardelean Professor PhD \\ dorina_ardelean@yahoo.com \\ Loredana Pribac Assistant PhD \\ pribacloredana@gmail.com \\ Cristian Haiduc Professor PhD \\ c_haiduc@uvvg.ro \\ Andrei Anghelina Associate Professor PhD \\ a_anghelina@uvvg.ro \\ "Vasile Goldis" Western University of Arad
}

(Received August 2016; Accepted October 2016)

\begin{abstract}
The emergence of the female entrepreneurial social class is certain and convincing in many countries, including Romania. Through this study we wish to portray a relevant image regarding the situation of female entrepreneurship in Romania. The starting point and a question to which many seek answers are: What was and is the economic strength of female entrepreneurship in Romania? After a short historical presentation regarding the evolution of feminine entrepreneurship, we presented the analysis of results after 25 years of democracy and capitalism. The main inference that we have deducted was: that the number of female entrepreneurs is on ascending path.
\end{abstract}

Keywords: female entrepreneurship, economic activities, Romania

JEL Classification: E20, E32, I29

\section{Introduction}

Entrepreneurship is subjected too much debate and analyzed from countless viewpoints, one of these aspects intrigues a dilemma with the following question attached: Female entrepreneurs or male entrepreneurs?

However until we discuss the current state of entrepreneurship there were several phases of transformation, especially regarding female entrepreneurship.

Some other issues directly related to entrepreneurship are:

- How much time do women spend working compared to men?

- What areas preferred by women? What areas preferred by men?

- Did they choose the right field?

- What are the incentives of entrepreneurial activities?

- What is the economic strength of female entrepreneurship?

Entrepreneurs... In literature, entrepreneurs are defined in many forms: different schools see the entrepreneur as a "discoverer", always looking for new 
opportunities; as an "appraiser" and, as an "exploiter" of new opportunities and the creator of new combinations. (OECD, 2012)

A general trait in empirical literature is the fact that entrepreneurs always take a greater risk when compared to average people and have the capability to perform several different tasks.

Entrepreneurs are those types of person (business owners) who want to generate value, through the creation or expansion of economic activity, through identifying and the exploitation of new products, processes and markets.

Female entrepreneurs in the world - a few success stories:

- Marie Curie - 1903 first woman to win a Nobel Prize

- Coco Chanel - 1910 - among the very first female entrepreneurs

- Carolina Mikkelsen - 1935 - the first woman to make it to Antarctic

- Amelia Mary Earhart - 1937 - the first female pilot that flew over the Atlantic Ocean

- Margaret Thatcher - 1979 - the first woman in Europe to lead a country female entrepreneurs in Romania:

- Sarmiza Bilcescu 1867-1935 - the first female lawyer, the first woman in Europe to obtain a law degree and the first woman in the world to have a doctoral degree in law

- Eliza Leonida Zamfirescu 1887-1973 - the first female engineer in the world

- Sofia Ionescu-Ogrezeanu 1920-2008 - the first female doctor specialized in neurosurgery in the world

- Lucia Sturdza-Bulandra - 1873-1961 - among the first female entrepreneurs (theater)

- Ana Aslan - 1897-1988 - the founder of Gerovital and Aslavital, doctor specialized in gerontology

(Paul, A. 2016, p. 25-26)

The question is: what common trait do all these women share? And the answer is: COURAGE... they took a risk and became the pioneers in their field of activity.

This study intends to highlight the role that women entrepreneurs in Romania have had in past, but also the role that they still have in the process of developing the economy.

\section{Highlights in the History of Female Entrepreneurship in Romania}

In the beginning, a few centuries ago, there were isolated cases in which women have learned, (either by need or want) to perform activities that today we call entrepreneurial activities. Here are a few examples: 
- Lady Chiajna, the wife of Ruler Mircea Ciobanul - in 1575 has dealt with trading small trinkets or small things

- Nicolae Iorga in his writings describes that Marica, the wife of Ruler Constantin Brancoveanu, after the death of her whole family involves herself in business deals in order to survive. (Iorga, N. 1911, p.23)

- After the Revolution of 1848 the leader of the Romanian Countries being very engaged with political nature of the country, thus being forced to leave their spouses in charge of family property and goods management (for example: Alexandrina, the wife of Ion Ghica, or another example is Zoe Golescu).

- In 1634 - Ruler Matei Basarab refers to Neaga, a woman who owned a shop, thus a business woman.

- In 1794 - Metropolitan Dositei recalls of women who worked in pubs.

- In 1813 - Voda Caragea recalls the first female doctor, Venetiana Vaduva.

- In the rule of Cuza there are many documents in which women are recalled as public traders, by reason of owning shops and practicing the activity of buying and selling.

- In 1906 - the first entrepreneur in Mamaia resort was a woman by the name of Ecaterina D. Nicolaescu.

(Paul, A. 2016, p. 18-19)

In the 19th century women who have performed diverse activities were seen as being poor and part of lower social standing. However there were women who by virtue of their social standing have decided to finance certain activities, such as investing in the printing of media publications, an example being Revista noastra si Romania. (Baluta I., Cirstocea, I., 2003, p. 36)

We showcased a few important women and a few success stories from Romania, nevertheless the laws and society at that time were not prepared to accept the woman's role in economic activity, until later on. Therefore, not even during the time of the Revolution of 1848 , woman's role in society as a entrepreneur was nonexistent.

Civil Code from the reign of Alexandru Ioan Cuza takes a leap forward and acknowledges the woman's role in society as a participant, with certain limits, for instance: they did not hold the write to sign deals or practice certain crafts. They could become pharmacists, they can practice medicine, they can compete for both secondary and superior education seats, on the other hand they cannot become lawyers, or magistrates. (Paul, A. 2016, p. 20)

The process of industrialization of Romania has played in important role in regard to activities in which women can involve themselves, thus women could perform many more diverse jobs and crafts. 
In the modern age women are developing their management side combining it the social aspect and creating a positive effect on society. Through associative structures women run charitable organizations and schools of different types (these new structures are named today NGO's).

In 1895, the Women's League in Romania was founded which advocates equal rights between women and men; furthermore they encouraged the entrepreneurial activities of women (Mihailescu, S., 2002, p. 63).

History exposes that only until the 20th century the jurists from Romania started to alter the Civil Code, through which women and men to be equal in rights. Hitherto regarding women remuneration, these continue to be disadvantaged, thus before the First World War a governess received a wage of 1 leu/day, a worker 1,3 lei/day, and a maximum wage a woman could receive was being a teacher 3,5 lei/day (Paul, A. 2016, p. 15).

In the following part we will discuss the situation of women in entrepreneurship in Romania through the official statements received by the state institutions.

\section{Description of the methodology}

The scope of the study is to analyze the data from ONRC Romania (National Trade Register Office of Romania) and from the GEM (Global Entrepreneurship Monitor) website and in the end to have an correct image of the situation of the women entrepreneurship from Romania.

The first part of the study is about Romania and in the second part we selected countries from Central and South-East Europe, countries that are in the neighboring of Romania, because we want to have a comparison.

All the indicators chosen are relevant to entrepreneurial activity analysis.

\section{Women Entrepreneurs in Romania in the Third Millennium}

Female entrepreneurship is gaining ground in Romania and even stands out to represent a particular field that contributes to the economic growth of the country.

Similar to other countries, in Romania female entrepreneurs had to struggle with existing legislation, along with male entrepreneurs who didn't give them credibility, however in spite all these they managed to assert themselves in their chosen field and become meaningful and essential.

All this data displays the fact that the number of male entrepreneurs in Romania is larger than the number of female entrepreneurs, furthermore the trend in relation to the number of female entrepreneurs is on an ascending pattern.

The data published by the National Trade Register Office of Romania Dateless denotes that own of $42,40 \%$ of all businesses in the counties of Galati and Dolj. In Arad county that same number is just $35,30 \%$, and in the neighboring counties the 
numbers are higher, as follows women own 37,70\% of businesses in Bihor, 36,60 $\%$ in Cluj and 39,30 \% in Hunedoara. In Bucharest the percentage is 36,50 \% of businesses owned by women who are entrepreneurs.

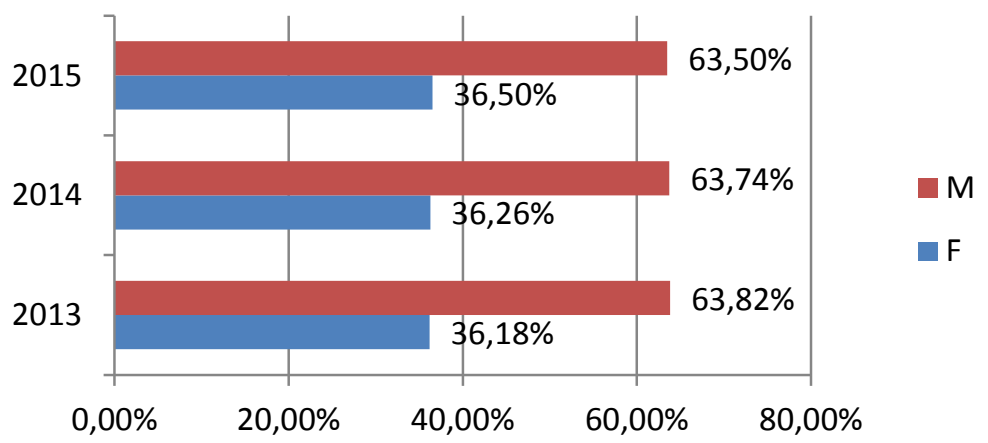

Figure 1. Evolution of the number of associates / shareholders of corporate assets in Romania - \%

Source: ONRC

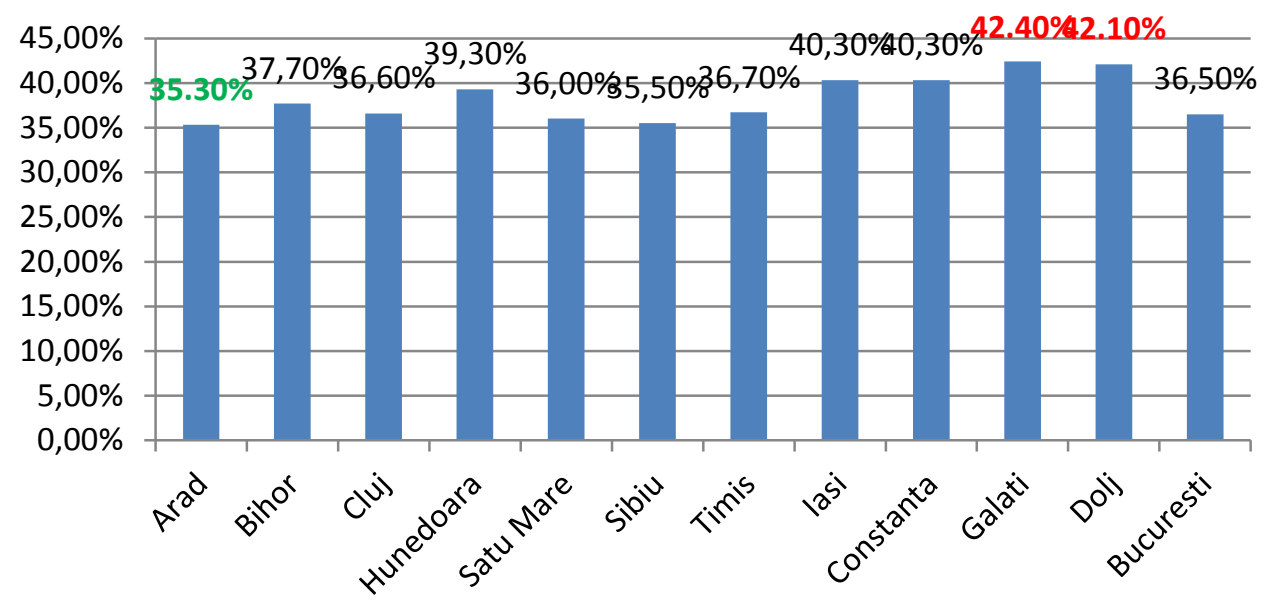

Figure 2. The percentage of the total number of companies accounted for by shareholders women $\mathbf{- 2 0 1 5}$ Source: ONRC

DE GRUYTER OPEN
Studia Universitatis "Vasile Goldis" Arad. Economics Series Vol 26 Issue 4/2016 ISSN: 1584-2339; (online) ISSN: 2285 - 3065 
Ardelean D., Pribac L., Haiduc C., Anghelina A. (2016)

The analysis of the emergence and development of female entrepreneurship in Romania

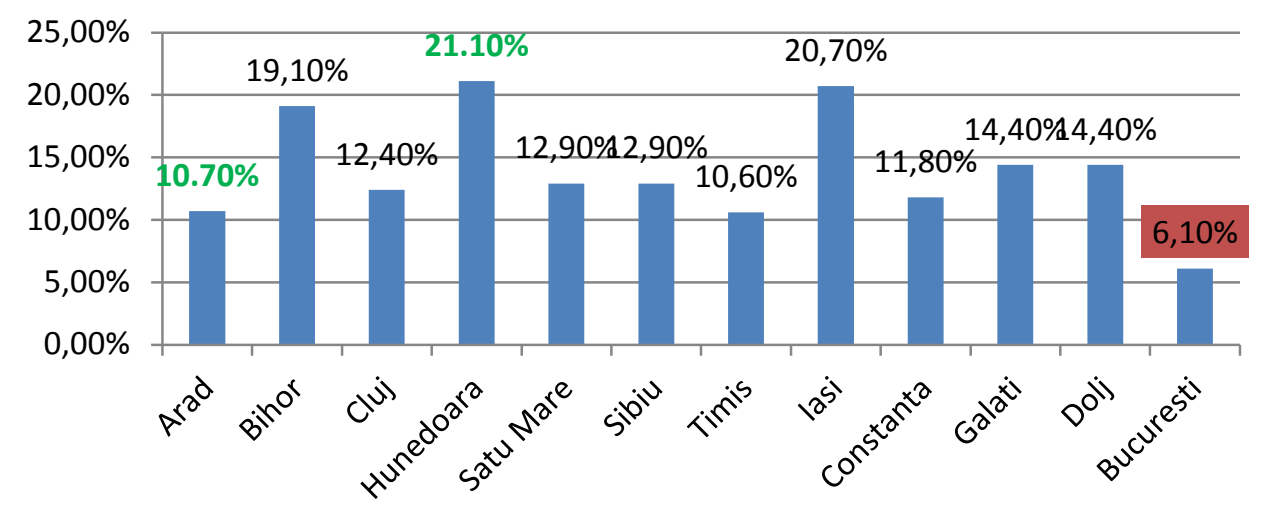

Figure 3. \% of total turnover - majority shareholders of companies with women 2015

Source: ONRC

The county with the largest revenues generated by companies that have female owners is Hunedoara, $21.10 \%$ of the total county revenue. Arad places itself at half of that amount, therefore $10.70 \%$ out of the total revenue in 2015. The smallest value is done by female entrepreneurs from Bucharest, after all there are many international large companies so it is quite normal for smaller companies to not be able to hold majority.

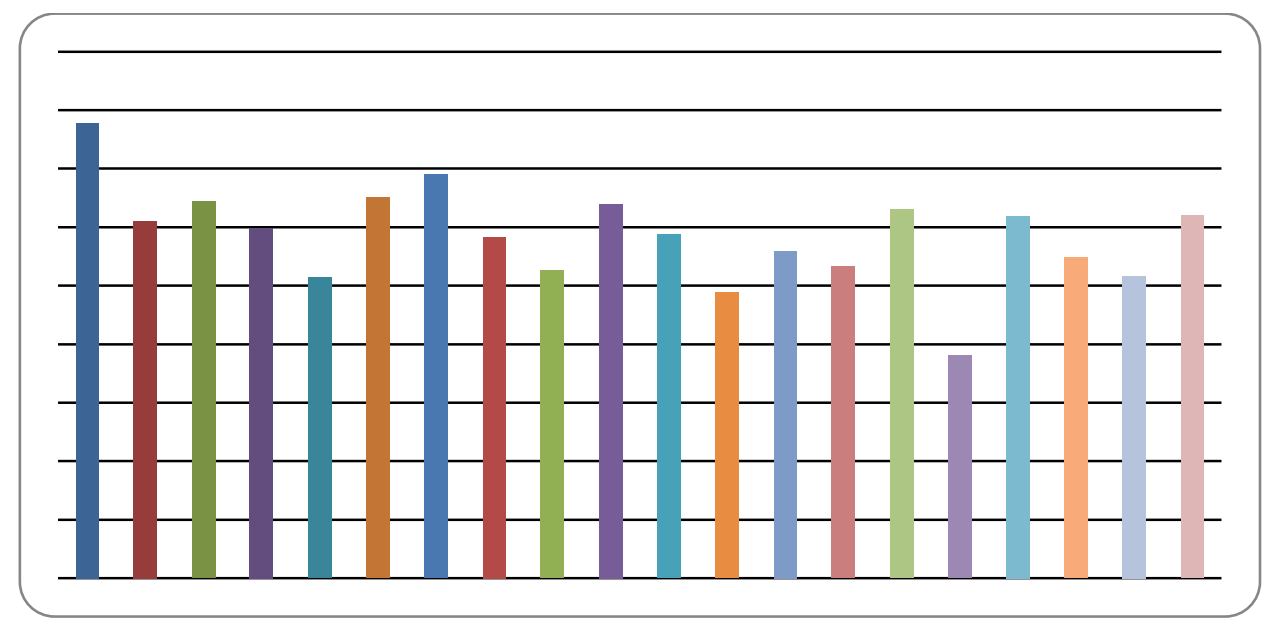

Figure 4. The main activities of companies owned by women - 2015

Source: ONRC 
The number of female entrepreneurs is higher in field that don't require physical strength or technical knowledge/ skills, considering that these field are where men excel, on the grounds that this is what they know best and it is suitable.

The fields in which female perform are as follows: administrative service, education, healthcare and culture. The data and the graph can be observed above.

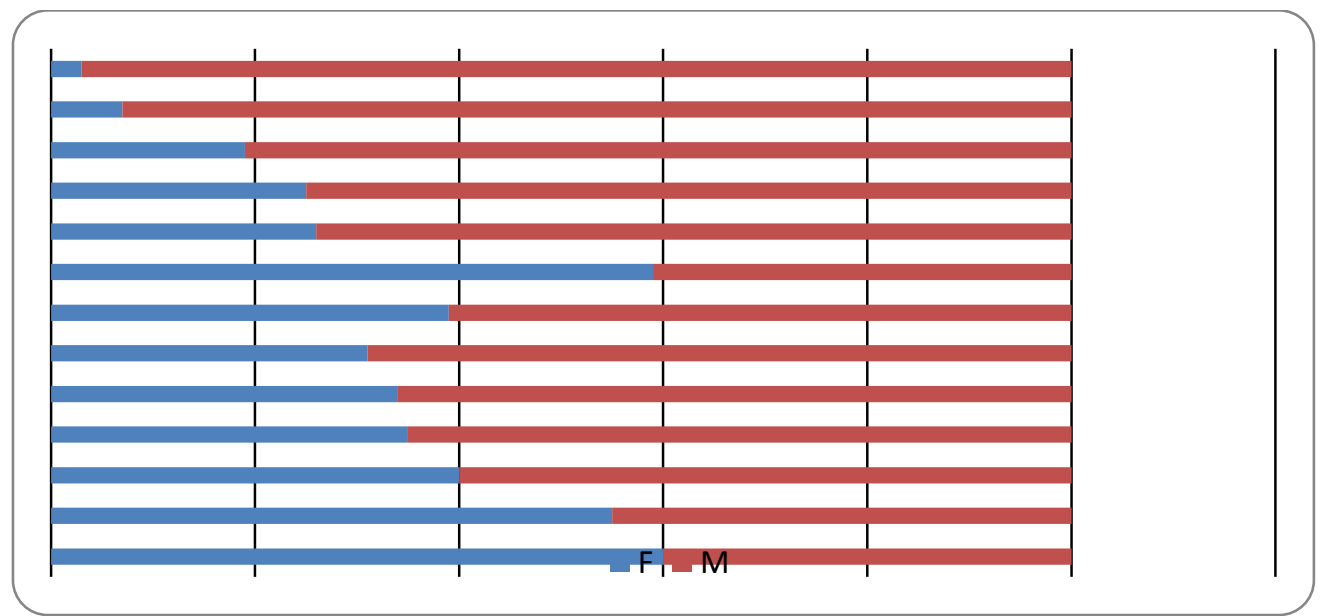

Figure 5. Sectors in which women were active - Europe 2012 Source: Eurostat

As you can see compared to Europe the activities which female entrepreneurs are engaged in are identical with those in Romania. The fields with the highest percentage of female occupation are (in descending order): healthcare, education and providing services, furthermore technical operations are fields mainly dominated by male counterparts.

The age of female entrepreneurs is an important factor, due to the fact that women decide to start a business after they have gained an array of skills, information and experience which bolsters their self-esteem.

According to data received from ONRC (National Trade Register Office of Romania), most of the female entrepreneurs are between 30 and 49 of age, almost $60 \%$ of women that own a business in Romania are within this age group.

Until 29 and after 60 women commonly assume they are not in the right moment to choose entrepreneurship as a path in life. Mostly likely due to the lack of experience until the age of 30 , moreover after the age of 60 the lack the necessarily energy and stamina to start a new business, however it is quite relevant to know that many choose to start a business at the at rightfully assumed age or age group. 
Ardelean D., Pribac L., Haiduc C., Anghelina A. (2016)

The analysis of the emergence and development of female entrepreneurship in Romania

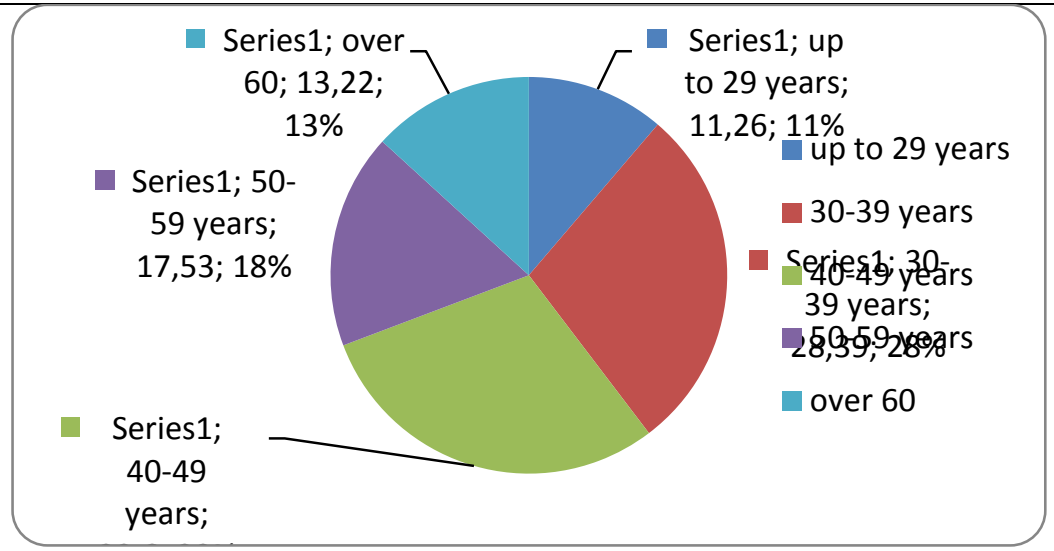

Figure 6. Age of Women Entrepreneurs - 2015

Source: ONRC

\section{The analysis of several indicators relevant to entrepreneurship}

Entrepreneurship needs to be supported by government and institutions of the State, especially female entrepreneurship. Below we will analyze several indicators that are important to the development of entrepreneurship in a country, especially for Romania.

After processing the data provided by GEM (Global Entrepreneurship Monitor) for the $11 \mathrm{EU}$ countries can be seen that the support of the government's offers to entrepreneurs is very different from country to country.

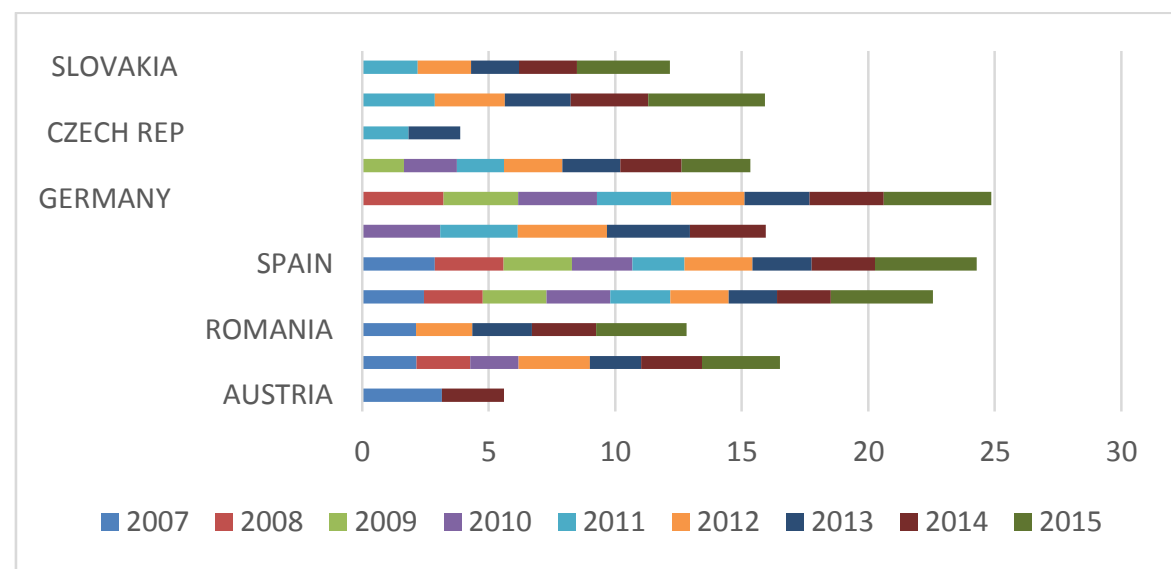

Figure 7. Governmental support and policies

Source: Global Entrepreneurship Monitor 
Entrepreneurial activity, as other areas such as education or culture, is still struggling to get more support from society and public institutions, but it can be seen that in Spain and Slovenia the indicator values are quite high. Czech Republic and Austria had values for this indicator just two years after the period of economic crisis, Czech Republic and Austria only in 2007 and 2014. Starting with 2014 all countries, except the Czech Republic, have values that represents the expansion of entrepreneurship and the support implicit received from the governments.

The evolution of indicator calculated on the support of the state institutions for entrepreneurial activity shows an increase in values for 2015 compared to 2007.

Slovakia enjoys the governmental support since 2011, compared to Romania which has values for 2007, but from 2008 until 2012 having values due to the international financial and economic crisis that precipitated the economic activities. Inevitably, the crisis has a negative impact on economic growth in Europe.

The received support from the public administration to the entrepreneurs is an important and not to be neglected aspect.

As can be seen in the figure no 4.2 only Slovenia and Italy have values for all the analyzed period (2007-2015) compared to other countries such as Czech Republic or France, that have the indicator on financing entrepreneurs small. Because entrepreneurial activities are still at the beginning pointer on financing entrepreneurs by public institutions is limited, but you can see that countries in Southeast Europe values are relevant.

If we analyze the evolution of values we can see that the trend is rising and the 2015 values are significantly higher than those in 2007.

A special case is Czech Republic who has values only for 2011-2013 (meaning post economic crisis).

Slovakia missing values in the years 2008 through 2011 due to the financial crisis that took place on those years, compared to Romania which has also suffered due to the crisis, just like all over Europe and beyond.

But even in these conditions Romania managed to pass and exceed this threshold, although it has not received large sums from the state like other neighboring countries.

As we can see from the above analysis not only entrepreneurs must produce all, they must be helped and encouraged by the State in which they operate. Neagu et all. (2016) in the study shows that employers and employees could have different views when they relate the content of organizational human capital and possibilities to enhance it, in order to increase the business performance.

Romania has enough flaws regarding entrepreneurship, yet with all these obstacles manages to grow from year to year. 


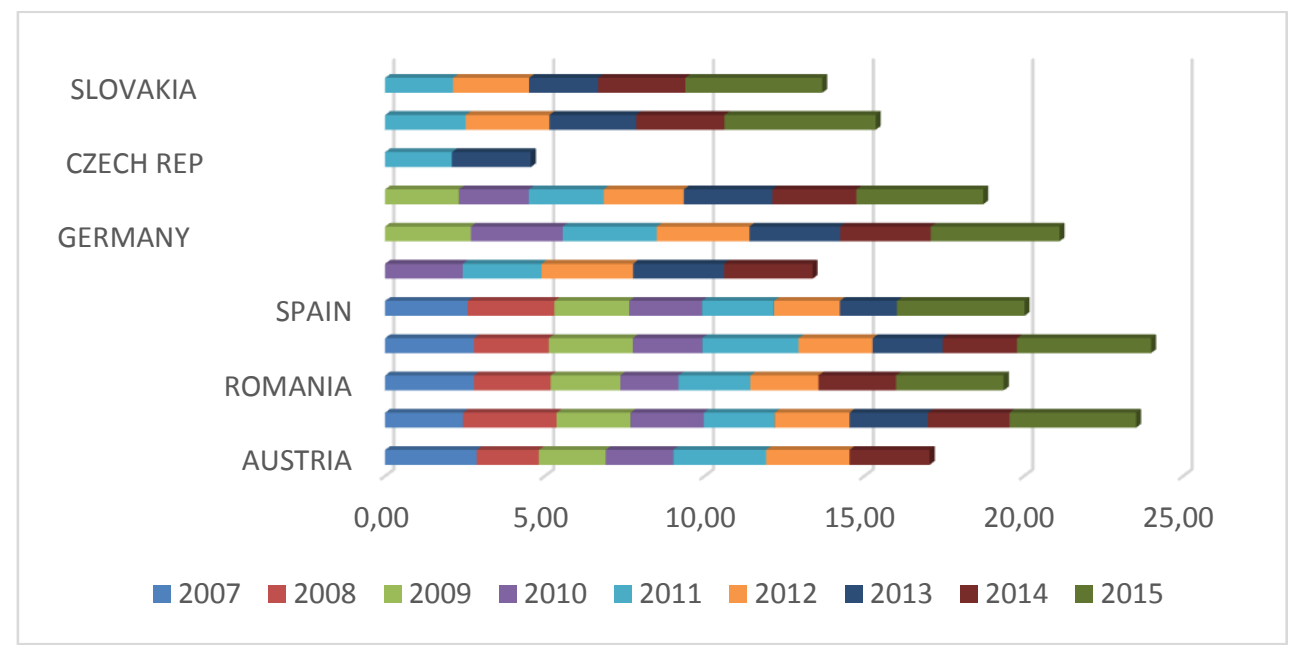

Figure 8. Financing for entrepreneurs

Source: Global Entrepreneurship Monitor

\section{Conclusions}

The development of a country is directly proportional with the expansion of entrepreneurial activities within the country, this fact has been proven by many previous studies, and we can confirm that we still have many items to work on regarding entrepreneurship, with an emphasis on female entrepreneurship.

Entrepreneurial activity contributes to economical growth through the creation of new jobs and advancing technology.

Female entrepreneurship in Romania has encountered many problems and barriers, and unfortunately is still facing a few of them (bureaucracy, discrimination), however with all these in mind it places itself on an ascending trend.

Female entrepreneurs from Romania wait to have adequate information gained and experience in order to start a business, which tells us a lot about the perspective with which they view this activity that is going to change their life and contribute positively to the economic growth of our the country.

In both the present and the past, Romania holds a few examples of female entrepreneurs with success stories at an international level worthy of being followed and used as case studies. We must keep a high standard and always try to overcome the current economic situation of the country.

In a future study we will try to identify features and traits of female entrepreneurs from West Romania, before the Revolution in 1989 and after this event. 
This study has research limits on behalf of the fact that not all the information regarding the evolution of female entrepreneurship in Romania are write in one place, and all that are in different documents are hard to find and access.

\section{Bibliography}

1. Ascher, J. (2012) - Female Entrepreneurship - An Appropriate Response to Gender Discrimination, Journal of Entrepreneurship, Management and Innovation (JEMI), Volume 8, Issue 4, pp. 97-114

2. Baluta, I., Cirstocea, I. (2003) - Directii si teme de cercetare in studiile de gen din Romania, Ecole Doctorale en Sciences Sociales. Europe Centrale si Colegiul Noua Europa, Bucuresti

3. Driga, O., Gonzalez, E. M. L. (2007) - Antreprenoriatul feminin in Romania: Caracteristici personale si efectul variabilelor socio-culturale, ISSN 1843-4428

4. Iorga, N. (1911) - Femeile in viata neamului nostru: chipuri, datine, fapte, marturii, Tipografia Neamului Romanesc, Valenii de Munte

5. Mihailescu, S. (2002) - "Din istoria feminismului romanesc. Antologie de texte (18381929)", Editura Polirom, Iasi

6. Neagu, O., Lazar, V. Teodoru, M., Macarie S. (2016) Human capital quality and development: an employers' and employees' comparative insight, Studia Universitatis "Vasile Goldis" Arad - Economics Series No. 26 Vol. 3

7. Niethammer-Odebrecht, C. (2013) - Women, Entrepreneurship and the Opportunity to Promote Development and Business, The Brookings Blum Roundtable Policy Briefs

8. Paul A. (2016) - Forta economica a femeilor Editura Polirom Bucuresti

9. Robb, A., Coleman, S., Stangler, D. (2014) - Sources of Economic Hope: Women's Entrepreneurship, The Ewing Marion Kauffman Foundation

10. Russell S. (2016) Entrepreneurship - The concise encyclopedia of economics http://www.econlib.org/library/Enc/Entrepreneurship.html

11. Santo, M. (2015) Women's Economic Empowerment both Nationally and Internationally - House of Lords http://researchbriefings.parliament.uk/ ResearchBriefing/Summary/LLN-2015-006\#fullreport

12. ***CEBR - Centre for Entrepreneurship \& Business Research - www.kfacts.ia.ro

13. ***Entrepreneurs http://www.entrepreneur.com/article/246815

14. ***Global Entrepreneurship Monitor http://www.gemconsortium.org

15. ***ILO (2014) - Women's Entrepreneurship Development

16. ***OECD (2012) - Measuring Women Entrepreneurship in Entrepreneurship at a Glance 2012, OECD Publishing

17. ***OECD (2013) - Women Entrepreneurs in the OECD http://www.oecdilibrary.org/docserver/download $/ 5 \mathrm{k} 43$ bvtkmb8v.pdf?expires $=1433233212 \& \mathrm{id}=\mathrm{id} \&$ acc name $=$ guest $\&$ checksum $=75841793$ D5532C5A0521CEC8C2E0ED78

18. ***ONRC www.onrc.ro

Studia Universitatis "Vasile Goldis" Arad. Economics Series Vol 26 Issue 4/2016 ISSN: 1584-2339; (online) ISSN: 2285 - 3065

Web: publicatii.uvvg.ro/index.php/studiaeconomia.Pages $67-77$ 